Supplement of Hydrol. Earth Syst. Sci., 26, 923-940, 2022

https://doi.org/10.5194/hess-26-923-2022-supplement

(c) Author(s) 2022. CC BY 4.0 License.

(c) (i)

Supplement of

\title{
Historical simulation of maize water footprints with a new global gridded crop model ACEA
}

Oleksandr Mialyk et al.

Correspondence to: Oleksandr Mialyk (o.mialyk@utwente.nl)

The copyright of individual parts of the supplement might differ from the article licence. 


\section{S1 Supplementary data and methods}

\section{S1.1 ACEA's grid cell outputs}

The annual outputs are divided into three groups:

- General outputs: 1) seeding/anthesis/harvest dates, 2) dry crop yield and above-ground biomass (both in $t \mathrm{ha}^{-1}$ ), 3) cumulative GDDs, 4) initial and final soil moisture (both in $\mathrm{mm}$ ), 5) elements of water balance, namely cumulative precipitation, irrigation requirement, capillary rise, groundwater inflow, evaporation, transpiration, runoff, deep percolation (all in $\mathrm{mm}$ ).

- Crop water use: cumulative actual evapotranspiration $(\mathrm{mm})$ split into three water types (green, blue from irrigation, and blue from capillary rise)

- Soil moisture storage: final soil moisture $(\mathrm{mm})$ split into three water types.

The daily outputs are also divided into three groups:

- Soil water content: soil water content for each soil compartment (fraction of the compartment depth).

- Water fluxes: 1) groundwater depth (m), 2) soil moisture, 3) precipitation, 4) irrigation requirement, 5) capillary rise, 6) groundwater inflow, 7) evaporation, 8) potential evaporation, 9) transpiration, 10) runoff, 11) deep percolation (all in $\mathrm{mm}$ ).

- Crop growth: 1) current and cumulative GDDs, 2) root depth (m), 3) actual canopy cover and one without stress (fraction of surface), 4) actual dry above-ground biomass and one without stress $\left(\mathrm{t} \mathrm{ha}^{-1}\right), 5$ ) actual harvest index and one without stress (fraction of biomass), 6) dry crop yield ( $\left.\mathrm{t} \mathrm{ha}^{-1}\right)$.

\section{S1.2 Changes to AquaCrop-OSPy code}

Several code adjustments are implemented:

1. Collection of outputs is adjusted to have all variables listed in Sect. S1.1.

2. Fixed minor errors originating in number rounding and loop settings.

3. Tracing of green water, blue water from irrigation, and blue water from capillary rise by tracking soil moisture composition in each soil compartment after any of next water balance-related functions in solution.py finishes its execution: check_groundwater_table, infiltration, drainage, capillary_rise, soil_evaporation, transpiration, groundwater_inflow.

4. To better simulate water stress responses in rainfed scenarios, some changes to core functions are done:

- We allow crop germination to be automatically triggered if there is a germination delay of more than 30 days. This happens when the topsoil moisture doesn't reach the germination TAW threshold of $20 \%$ (default value for all crops). 
- The crop calendar-depended parameters are recalculated if the germination is delayed. This allows the growing season to be extended (up to $15 \%$ ) and growth stages to be shifted according to their GDDs accumulation requirements.

- The first 30 days after germination are set to be free of water stress-induced senescence. This allows crops to start growing even in arid environments assuming that farmers would use more drought-resistant crop cultivars.

- Canopy cover is not allowed to go lower than the minimum harvestable $5 \%$ until the end of the yield formation.

All these changes are also considered in irrigated scenarios. However, the impact on them is neglectable because water availability is not limited. Consequently, the germination is triggered automatically on the next day after planting.

\section{S1.3 Plant density testing}

We test the sensitivity of unit $W F$ estimates of maize to three plant density values: 50000,75000 and 10000 plants ha $^{-1}$. As you can see from Table S1, CWU values barely change with an increase in plant density as also observed in other studies (Irmak and Djaman, 2016; Barbieri et al., 2012). On the other hand, maize yields do increase with an increase in plant density leading to smaller $W F$ values. In our study, we consider the fixed density of 75000 plants ha ${ }^{-1}$ as it is the most common value in literature.

Table S1. Average unit water footprint estimates for three plant densities of maize in northern Italy during 1986-2016. CWU is crop water use (g green, $b$ - blue).

\begin{tabular}{|c|c|c|c|c|c|c|c|}
\hline \multirow{2}{*}{$\begin{array}{c}\text { Plant } \\
\text { density } \\
(\text { plants ha-1) }\end{array}$} & \multicolumn{2}{|c|}{$\begin{array}{c}\text { Crop yield } \\
\left(\mathrm{t} \mathrm{ha}^{-1} \mathrm{y}^{-1}\right)\end{array}$} & \multicolumn{2}{c|}{$\begin{array}{c}\mathbf{C W U}_{\mathrm{g}} \\
\left(\mathrm{mm} \mathrm{y}^{-1}\right)\end{array}$} & $\begin{array}{c}\mathbf{C W U}_{\mathrm{b}} \\
\left(\mathrm{mm} \mathrm{y}^{-1}\right)\end{array}$ & \multicolumn{2}{c|}{$\begin{array}{c}\text { Unit water footprint } \\
\left(\mathrm{m}^{3} \mathrm{t}^{-1} \mathrm{y}^{-1}\right)\end{array}$} \\
\cline { 2 - 9 } & Rainfed & Irrigated & Rainfed & Irrigated & Irrigated & Rainfed & Irrigated \\
\hline 50000 & 7.2 & 13.5 & 343.5 & 309 & 187.6 & 477.1 & 367.9 \\
\hline 75000 & 7.2 & 14 & 341.7 & 308.3 & 194.1 & 474.6 & 358.9 \\
\hline 100000 & 7.4 & 14.3 & 341.4 & 310.6 & 195.7 & 461.4 & 354.1 \\
\hline
\end{tabular}

\section{S1.4 Generic maize characteristics}

\begin{tabular}{lc}
\hline Version of AquaCrop & 6.1 \\
\hline Crop Type (1 = Leafy vegetable, 2 = Root/tuber, 3 = Fruit/grain) & 3 \\
\hline Planting method (0 = Transplanted, 1 = Sown) & 1 \\
\hline Calendar Type (1 = Calendar days, 2 = Growing degree days) & 2 \\
\hline Growing degree/Calendar days from sowing to emergence/transplant recovery & 80 \\
\hline Growing degree/Calendar days from sowing to maximum rooting & 1400 \\
\hline Growing degree/Calendar days from sowing to senescence & 1400 \\
\hline Growing degree/Calendar days from sowing to maturity & 1700 \\
\hline Growing degree/Calendar days from sowing to start of yield formation & 880 \\
\hline Duration of flowering in growing degree/calendar days (-999 for non-fruit/grain crops) & 180 \\
\hline Duration of yield formation in growing degree/calendar days & 750 \\
\hline Growing degree day calculation method & 3 \\
\hline
\end{tabular}




\begin{tabular}{|c|c|}
\hline Base temperature (degC) below which growth does not progress & 8 \\
\hline Upper temperature (degC) above which crop development no longer increases & 30 \\
\hline Pollination affected by heat stress $(0=\mathrm{No}, 1=$ Yes $)$ & 1 \\
\hline Maximum air temperature (degC) above which pollination begins to fail & 40 \\
\hline Maximum air temperature (degC) at which pollination completely fails & 45 \\
\hline Pollination affected by cold stress $(0=\mathrm{No}, 1=\mathrm{Yes})$ & 1 \\
\hline Minimum air temperature (degC) below which pollination begins to fail & 10 \\
\hline Minimum air temperature (degC) at which pollination completely fails & 5 \\
\hline Transpiration affected by cold temperature stress $(0=$ No, $1=$ Yes $)$ & 1 \\
\hline Minimum growing degree days (degC/day) required for full crop transpiration potential & 12 \\
\hline Growing degree days (degC/day) at which no crop transpiration occurs & 0 \\
\hline Minimum effective rooting depth $(\mathrm{m})$ & 0.3 \\
\hline Maximum rooting depth $(\mathrm{m})$ & 2.3 \\
\hline Shape factor describing root expansion & 1.3 \\
\hline Maximum root water extraction at top of the root zone (m3/m3/day) & 0.0104 \\
\hline Maximum root water extraction at the bottom of the root zone (m3/m3/day) & 0.0026 \\
\hline Soil surface area $(\mathrm{cm} 2)$ covered by an individual seedling at $90 \%$ emergence & 6.5 \\
\hline Number of plants per hectare & 75000 \\
\hline Maximum canopy cover (fraction of soil cover) & 0.96 \\
\hline Canopy decline coefficient (fraction per GDD/calendar day) & 0.01 \\
\hline Canopy growth coefficient (fraction per GDD) & 0.01245 \\
\hline Crop coefficient when canopy growth is complete but prior to senescence & 1.05 \\
\hline Decline of crop coefficient due to ageing (\%/day) & 0.3 \\
\hline Water productivity normalized for ET0 and C02 $(\mathrm{g} / \mathrm{m} 2)$ & 33.7 \\
\hline Adjustment of water productivity in yield formation stage (\% of WP) & 100 \\
\hline Crop performance under elevated atmospheric CO2 concentration (\%) & 50 \\
\hline Reference harvest index & 0.48 \\
\hline Possible increase of harvest index due to water stress before flowering (\%) & 0 \\
\hline Coefficient describing positive impact on harvest index of restricted vegetative growth during yield formation & 7 \\
\hline Coefficient describing negative impact on harvest index of stomatal closure during yield formation & 3 \\
\hline Maximum allowable increase of harvest index above reference value & 15 \\
\hline Crop Determinancy $(0$ = Indeterminant, 1 = Determinant) & 1 \\
\hline Excess of potential fruits & 50 \\
\hline Upper soil water depletion threshold for water stress effects on affect canopy expansion & 0.14 \\
\hline Upper soil water depletion threshold for water stress effects on canopy stomatal control & 0.69 \\
\hline Upper soil water depletion threshold for water stress effects on canopy senescence & 0.69 \\
\hline Upper soil water depletion threshold for water stress effects on canopy pollination & 0.8 \\
\hline Lower soil water depletion threshold for water stress effects on canopy expansion & 0.72 \\
\hline Lower soil water depletion threshold for water stress effects on canopy stomatal control & 1 \\
\hline Lower soil water depletion threshold for water stress effects on canopy senescence & 1 \\
\hline Lower soil water depletion threshold for water stress effects on canopy pollination & 1 \\
\hline Shape factor describing water stress effects on canopy expansion & 2.9 \\
\hline Shape factor describing water stress effects on stomatal control & 6 \\
\hline Shape factor describing water stress effects on canopy senescence & 2.7 \\
\hline Shape factor describing water stress effects on pollination & 1 \\
\hline Vol (\%) below saturation at which stress begins to occur due to deficient aeration & 5 \\
\hline Number of days lag before aeration stress affects crop growth & 3 \\
\hline
\end{tabular}




\section{S1.5 Soil profile selection}

In AquaCrop, the soil profile is divided into several compartments (Vanuytrecht et al., 2014). The thickness of a compartment is usually set to a minimum at the top of the soil profile (to increase the accuracy of soil evaporation estimations), and to a maximum at the bottom (where water fluxes are less important). By default, the model suggests using a profile with 12 compartments starting with $10 \mathrm{~cm}$ thickness for the first three compartments and reaching $30 \mathrm{~cm}$ for the last one. However, recent literature shows that the selection of compartments is task-specific, and thus there is no general rule of thumb (Mkhabela and Bullock, 2012). Therefore, the default 12 compartments setup is simplified. We test three soil profiles in this study (Table S2). A total depth of 3 meters is chosen to cover the maximum root depth of maize. The tests are performed for rainfed maize during 1993-2012 with the initial soil moisture of 50\% TAW for the whole soil profile. Following the setup of Chukalla et al. (2015), four climatic zones (arid, semi-arid, semi-humid, humid) and three soil types (real reported soil in literature, sandy loam and silty clay loam) are tested for each soil profile making 36 scenarios in total. No shallow groundwater is considered.

Table S2. Selection of $3 \mathbf{m}$ thick soil profiles for testing in ACEA.

\begin{tabular}{|c|c|c|c|}
\hline $\begin{array}{c}\text { Compartment } \\
\text { number }\end{array}$ & Soil profile 1 & Soil profile 2 & Soil profile 3 \\
\hline 1 & 0.2 & 0.1 & 0.1 \\
\hline 2 & 0.3 & 0.1 & 0.1 \\
\hline 3 & 0.5 & 0.1 & 0.1 \\
\hline 4 & 0.8 & 0.3 & 0.2 \\
\hline 5 & 1.2 & 0.4 & 0.2 \\
\hline 6 & & 0.6 & 0.2 \\
\hline 7 & & 0.7 & 0.2 \\
\hline 8 & & 0.7 & 0.2 \\
\hline 9 & & & 0.2 \\
\hline 10 & & & 0.2 \\
\hline 11 & & & 0.2 \\
\hline 12 & & & 0.2 \\
\hline 13 & & & 0.3 \\
\hline 14 & & & 0.3 \\
\hline 15 & & & 0.3 \\
\hline
\end{tabular}

Soil profile 3 has the highest number of compartments. Therefore, it is set as a benchmark for comparisons with soil profiles 1 and 2. For the comparisons, the T-test function in Excel is used. Consequently, the soil profile with the least difference from the benchmark is optimum. The parameters to compare are the soil moisture at 0.3 and $1 \mathrm{~m}$ depths on the crop planting and harvest dates. In total, the comparisons are made for 48 combinations of soil moisture depths with climate and soil scenarios. According to T-test results, soil profile 1 with five compartments has a significant difference between soil moistures in $79 \%$ of the comparisons (38 out of 48) and soil profile 2 with eight compartments in only 12\% of the comparisons (6 out of 48 ). That $12 \%$ of comparisons are always for the semi-arid and semi-humid locations at $1 \mathrm{~m}$ depth on the harvest date. However, 
the soil moisture differences in absolute terms are minor and do not affect the crop modelling outputs. Therefore, no further tests are performed and soil profile 2 is selected for further use.

\section{S1.6 Generation of initial soil moisture}

Initial soil moisture has a significant impact the crop development, especially in arid and semi-arid climate zones (Rossato et al., 2017). Consequently, it is important to provide accurate water content values when a growing season starts. In our study, we test several scenarios to identify the number of years required to generate realistic soil moisture conditions. The same setup as for the soil profile selection is considered (four climates and three soil types). The soil profile is set to eight compartments and no shallow groundwater is considered.

We see that only the soil water content of the first growing season for an arid location is affected by the initial soil moisture assumptions. Consequently, the crop modelling outputs of the first growing season are inaccurate. Therefore, to analyse the crop modelling results of the year 1986, the simulations need to start in advance. For summer crops it corresponds to a oneyear spin-up period and for winter crops it corresponds to two years. To unify the modelling setup, a two-year spin-up period is selected for all crops with a 50\% green water TAW on the first day of simulation (1 January 1984).

\section{S1.7 Groundwater level limitation}

To avoid crop aeration stress, we lower the minimum groundwater depth to $1 \mathrm{~m}$ under the assumption that farmers would drain the area to maximise crop yields. This assumption is validated by simulating rainfed maize production in the Netherlands with groundwater depth limited to $0.5,1$, and $1.5 \mathrm{~m}$. While there is no difference in crop yields with two latter limits, the maize production dropped by $25-30 \%$ when the limit is $0.5 \mathrm{~m}$. Moreover, this assumption is supported by literature on the optimal shallow groundwater depth for crop production (Kahlown et al., 2005).

\section{S1.8 Extrapolation of SPAM2010}

To extrapolate 5 x 5 arc minute maize harvested areas around 2010 from SPAM2010 (Yu et al., 2020) into 1986-2016, two gridded datasets on the historical cropland are used - HYDE3.2 (Klein Goldewijk et al., 2017) and HID (Siebert et al., 2015). The procedure differs for rainfed and irrigated crops.

For rainfed maize, we firstly extract the rainfed cropland from HYDE3.2 for the time period of 1980-2016. The period before 2000 is reported in 10-year timesteps. Therefore, we interpolate values between 1980 and 2000 to have annual time-series for each grid cell (using scipy.interpolate package in Python). Then, we estimate the cropland extent around the year 2010 by taking the average of 2008-2012 (HYDE2010). After, we normalize the historical cropland values to the HYDE2010 value. This allows us to extrapolate SPAM2010 by assuming that rainfed maize areas experienced the same historical changes as the normalized rainfed cropland (eq. S1). Finally, we take a lower value between the extrapolated SPAM2010 and original HYDE3.2 values to avoid two outcomes: 1) maize harvest areas being larger than the cropland, and 2) maize harvest areas being more than 0 ha in years when no rainfed cropland is reported. 


$$
A_{\text {rainfed }}=\min \left(S P A M 2010 * \frac{H Y D E 3.2}{H Y D E 2010}, \quad\right. \text { HYDE3.2) }
$$

For irrigated maize, the procedure is more complex. Firstly, we extract the irrigated cropland from HYDE3.2 for the time period of 1980-2016 and from HID for the time period of 1985-2005. Same as for rainfed, we interpolate the values between 1980 and 2000 in HYDE3.2 and between the whole period in HID as it is reported with 5-year timesteps. Then, we use HYDE3.2 to extrapolate HID values until 2016. This is done by multiplying the HID value in 2005 with 2006-2016 values from HYDE3.2 normalized to the year 2005. The next steps are similar to the procedure for rainfed maize but HID values are used instead of HYDE3.2 (eq. S2). We prioritise HID dataset as it provides better coherence with globally reported statistics (Siebert et al., 2015).

$$
A_{\text {irrigated }}=\min \left(S P A M 2010 * \frac{H I D}{H I D 2000}, \quad H I D\right)
$$

As a result, each $5 \times 5$ arc minute grid cell has a historical harvest area of rainfed and irrigated maize production. However, these values may not reflect the official national statistics reported by FAOSTAT (FAOSTAT, 2021). Therefore, we aggregate the extrapolated SPAM2010 data to the national level and scale it to ensure that the sum of harvest areas (both rainfed and irrigated) within a country is equal to the respective national statistic in a specific year. Note that, due to limitations on data availability, there are no new grid cells with maize production other than reported in SPAM2010. However, some cells can have no production if the corresponding country does not report it. For example, Denmark started producing maize only in 2010, and thus there were no harvested areas until that year. 


\section{S2 Supplementary results}
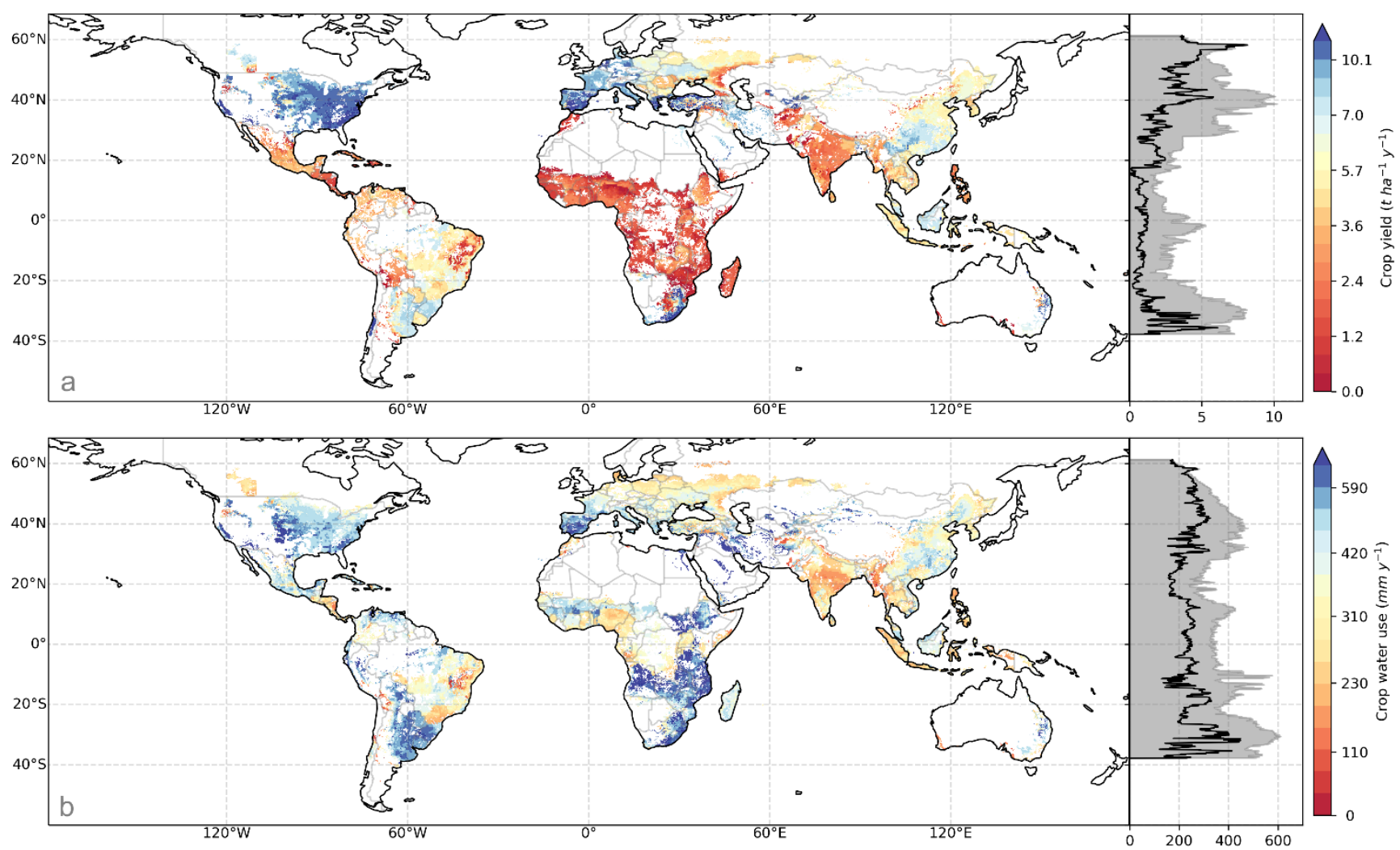

Figure S1: Average yields (a) $\left(\mathrm{t} \mathrm{ha}^{-1} \mathrm{y}^{-1}\right)$ and crop water use (c) $\left(\mathrm{mm} \mathrm{y}^{-1}\right)$ of maize as the average over 2012-2016 at $5 \mathrm{x} 5$ arc minute resolution. The grey area in the side chart represents the median of all data points along the respective latitude and the black line is the 10th percentile. 

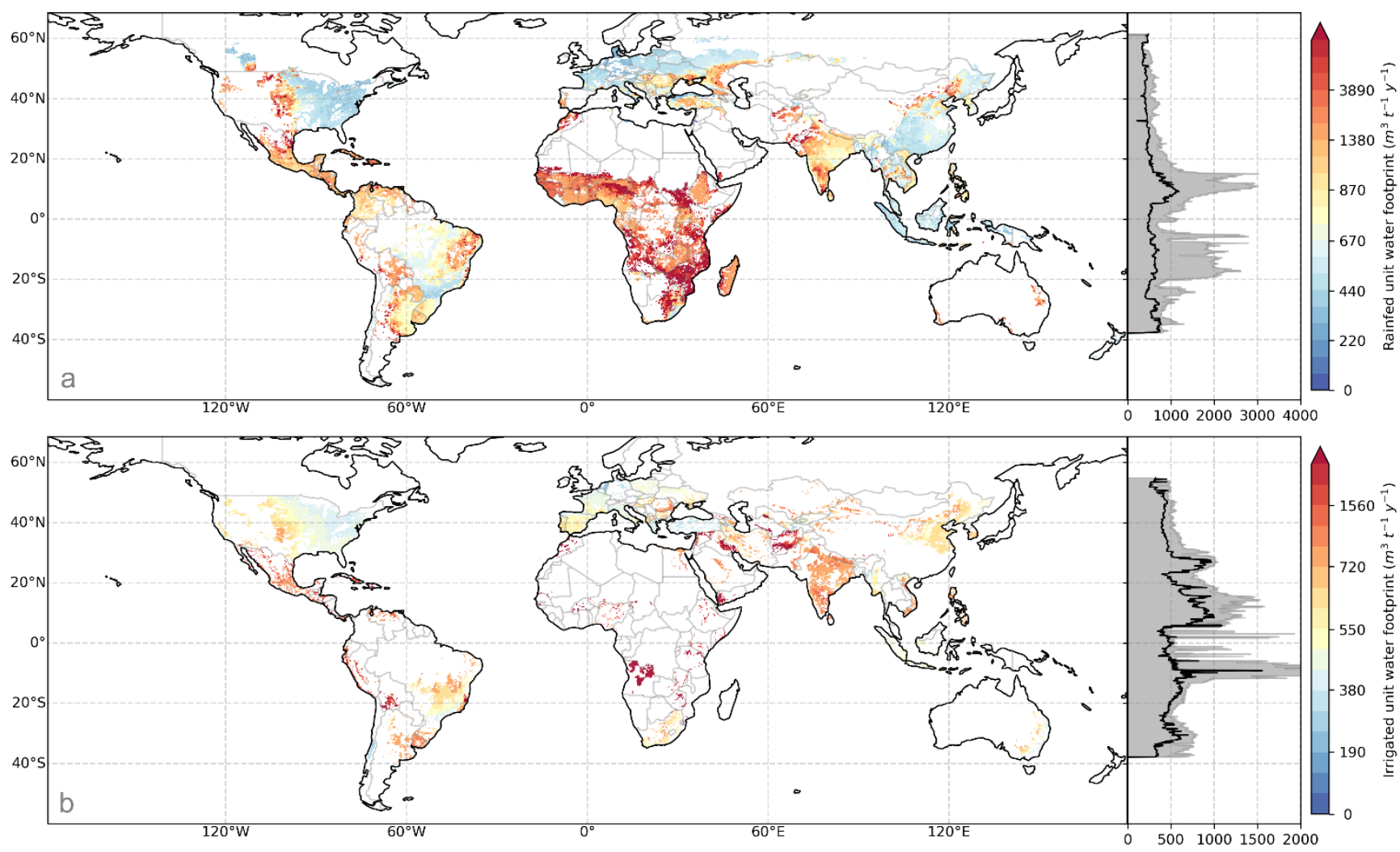

Figure S2: Average unit water footprint of rainfed (a) and irrigated (b) maize $\left(\mathrm{m}^{3} \mathrm{t}^{-1} \mathrm{y}^{-1}\right)$ as the average over 2012-2016 at $5 \times 5$ arc minute resolution. The grey area in the side chart represents the median of all data points along the respective latitude and the black line is the 10th percentile. 

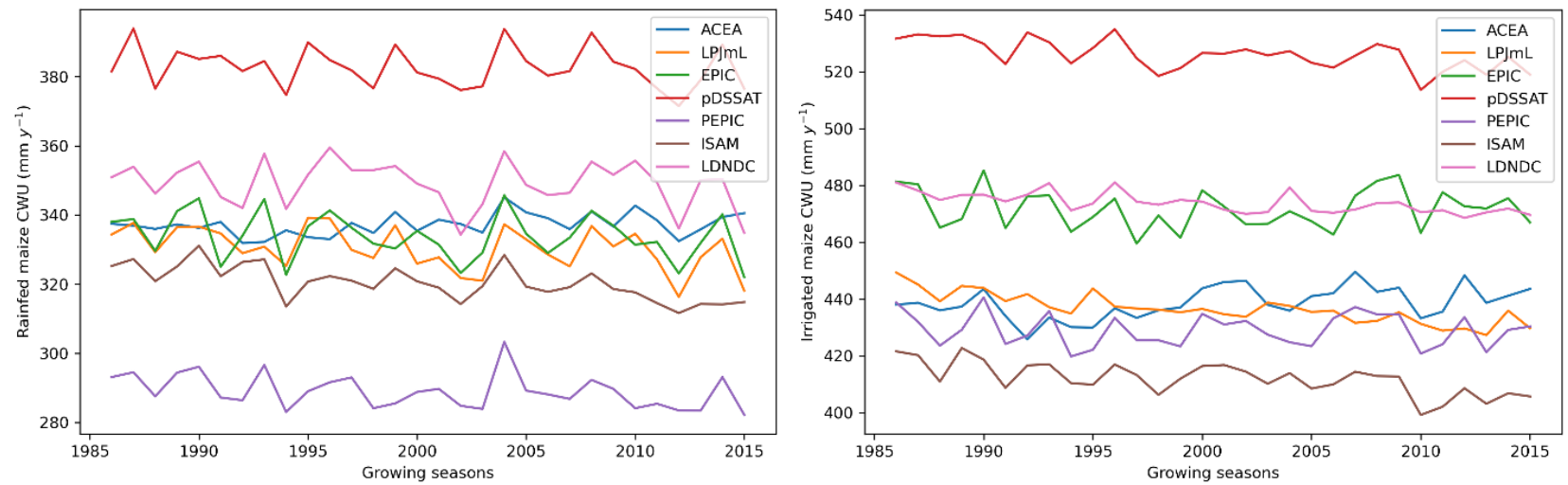

Figure S3: Global comparison of crop water use (CWU) of rainfed and irrigated maize ( $\left.\mathrm{mm} \mathrm{y}^{-1}\right)$ with Jägermeyr et al. (2021). Each line represents an annual median value among the cells with CWU more than $10 \mathrm{~mm}$ simulated by one of global gridded crop models. 
Table S3. National average water footprints and production of maize as the average over 2012-2016. WF is water footprint ( $\mathrm{g}$ - green, bc - blue from capillary rise, bi - blue from irrigation).

\begin{tabular}{|c|c|c|c|c|c|c|c|c|c|c|}
\hline \multirow{2}{*}{ \# } & \multirow{2}{*}{ Country } & \multirow{2}{*}{$\begin{array}{c}\text { FAOST } \\
\text { AT } \\
\text { code }\end{array}$} & \multirow{2}{*}{$\begin{array}{l}\text { Production } \\
\left(10^{6} \mathrm{t}^{-1}\right)\end{array}$} & \multirow{2}{*}{$\begin{array}{l}\text { Harvested } \\
\text { area } \\
\left(10^{3} \text { ha } \mathrm{y}^{-1}\right)\end{array}$} & $W F_{g}$ & $W F_{b c}$ & $\mathbf{W F}_{\mathrm{bi}}$ & \multirow{2}{*}{$\begin{array}{l}\text { Unit WF } \\
\left(\mathrm{m}^{3} \mathrm{t}-1 \mathrm{y}^{-1}\right)\end{array}$} & \multirow{2}{*}{\begin{tabular}{|c|} 
Change in \\
unit WF \\
(relative to 1986- \\
$1990)$
\end{tabular}} & \multirow{2}{*}{$\begin{array}{c}\text { Change in } \\
\text { WF of production } \\
\text { (relative to 1986- } \\
1990 \text { ) }\end{array}$} \\
\hline & & & & & \multicolumn{3}{|c|}{ (\% of unit WF) } & & & \\
\hline \multicolumn{11}{|c|}{ Countries that produce $95 \%$ of maize } \\
\hline 1 & USA & 231 & 343.7 & 34435.0 & $90.1 \%$ & $1.7 \%$ & $8.3 \%$ & 487.2 & $-28.6 \%$ & $35.8 \%$ \\
\hline 2 & China & 41 & 233.1 & 39523.5 & $85.4 \%$ & $1.9 \%$ & $12.7 \%$ & 614.1 & $-30.7 \%$ & $99.5 \%$ \\
\hline 3 & Brazil & 21 & 75.5 & 15057.7 & $99.8 \%$ & $0.1 \%$ & $0.2 \%$ & 633.2 & $-62.6 \%$ & $17.7 \%$ \\
\hline 4 & Argentina & 9 & 31.9 & 4674.0 & $94.4 \%$ & $4.6 \%$ & $1.0 \%$ & 816.8 & $-48.5 \%$ & $102.2 \%$ \\
\hline 5 & Ukraine & 230 & 26.3 & 4432.3 & $97.3 \%$ & $0.7 \%$ & $2.0 \%$ & 584.2 & $-40.2 \%$ & $108.2 \%$ \\
\hline 6 & Mexico & 138 & 24.1 & 7155.5 & $89.4 \%$ & $0.1 \%$ & $10.5 \%$ & 1252.4 & $-46.7 \%$ & $7.2 \%$ \\
\hline 7 & India & 100 & 23.7 & 9197.6 & $95.2 \%$ & $0.3 \%$ & $4.6 \%$ & 982.0 & $-46.1 \%$ & $57.5 \%$ \\
\hline 8 & Indonesia & 101 & 19.9 & 3969.6 & $98.6 \%$ & $0.2 \%$ & $1.1 \%$ & 555.6 & $-60.5 \%$ & $26.7 \%$ \\
\hline 9 & France & 68 & 14.9 & 1691.7 & $93.0 \%$ & $0.1 \%$ & $6.8 \%$ & 480.6 & $-17.0 \%$ & $-0.6 \%$ \\
\hline 10 & Canada & 33 & 13.2 & 1383.1 & $98.2 \%$ & $1.8 \%$ & $0.0 \%$ & 378.7 & $-31.6 \%$ & $40.1 \%$ \\
\hline 11 & Russian Federation & 185 & 12.0 & 2461.2 & $96.4 \%$ & $3.6 \%$ & $0.0 \%$ & 697.4 & $-35.8 \%$ & $133.6 \%$ \\
\hline 12 & South Africa & 202 & 11.0 & 2553.6 & $87.7 \%$ & $0.0 \%$ & $12.3 \%$ & 1011.0 & $-61.6 \%$ & $-54.9 \%$ \\
\hline 13 & Nigeria & 159 & 10.3 & 6388.8 & $99.5 \%$ & $0.2 \%$ & $0.3 \%$ & 1658.2 & $-16.5 \%$ & $79.2 \%$ \\
\hline 14 & Romania & 183 & 10.0 & 2583.9 & $96.4 \%$ & $2.1 \%$ & $1.5 \%$ & 952.8 & $-19.0 \%$ & $3.5 \%$ \\
\hline 15 & Egypt & 59 & 7.9 & 1039.9 & $1.0 \%$ & $0.0 \%$ & $99.0 \%$ & 1002.5 & $-33.3 \%$ & $28.2 \%$ \\
\hline 16 & Italy & 106 & 7.8 & 828.9 & $85.5 \%$ & $6.1 \%$ & $8.4 \%$ & 456.4 & $-10.3 \%$ & $14.3 \%$ \\
\hline 17 & Ethiopia & 238 & 7.7 & 2751.3 & $99.4 \%$ & $0.0 \%$ & $0.6 \%$ & 1918.2 & $-43.3 \%$ & $166.1 \%$ \\
\hline 18 & Philippines & 171 & 7.4 & 2563.1 & $99.6 \%$ & $0.2 \%$ & $0.2 \%$ & 803.0 & $-60.4 \%$ & $-34.5 \%$ \\
\hline 19 & Hungary & 97 & 7.2 & 1156.6 & $92.8 \%$ & $6.9 \%$ & $0.4 \%$ & 622.4 & $-8.0 \%$ & $2.5 \%$ \\
\hline 20 & United Republic of Tanzania & 215 & 6.1 & 4014.4 & $99.6 \%$ & $0.1 \%$ & $0.2 \%$ & 3782.1 & $-12.8 \%$ & $109.8 \%$ \\
\hline 21 & Serbia & 272 & 5.9 & 1006.9 & $94.4 \%$ & $5.6 \%$ & $0.0 \%$ & 706.0 & $-31.0 \%$ & $-32.3 \%$ \\
\hline 22 & Turkey & 223 & 5.4 & 660.6 & $81.1 \%$ & $0.1 \%$ & $18.7 \%$ & 401.0 & $-42.2 \%$ & $45.0 \%$ \\
\hline 23 & Viet Nam & 237 & 5.2 & 1164.3 & $96.0 \%$ & $0.3 \%$ & $3.6 \%$ & 829.6 & $-66.8 \%$ & $150.0 \%$ \\
\hline 24 & Pakistan & 165 & 5.1 & 1182.0 & $70.3 \%$ & $0.0 \%$ & $29.7 \%$ & 767.3 & $-64.4 \%$ & $55.5 \%$ \\
\hline 25 & Thailand & 216 & 4.7 & 1111.3 & $99.2 \%$ & $0.8 \%$ & $0.0 \%$ & 617.7 & $-45.0 \%$ & $-34.7 \%$ \\
\hline 26 & Germany & 79 & 4.6 & 475.3 & $98.5 \%$ & $0.6 \%$ & $0.9 \%$ & 341.0 & $-22.5 \%$ & $148.7 \%$ \\
\hline 27 & Spain & 203 & 4.5 & 401.8 & $42.4 \%$ & $0.0 \%$ & $57.6 \%$ & 538.0 & $-37.6 \%$ & $-17.2 \%$ \\
\hline 28 & Paraguay & 169 & 4.2 & 947.0 & $100.0 \%$ & $0.0 \%$ & $0.0 \%$ & 1175.0 & $-55.8 \%$ & $449.1 \%$ \\
\hline 29 & Poland & 173 & 3.9 & 620.0 & $99.4 \%$ & $0.4 \%$ & $0.2 \%$ & 477.9 & $-15.0 \%$ & $1589.6 \%$ \\
\hline 30 & Kenya & 114 & 3.7 & 2166.9 & $99.8 \%$ & $0.0 \%$ & $0.2 \%$ & 2073.4 & $12.7 \%$ & $56.7 \%$ \\
\hline 31 & Malawi & 130 & 3.3 & 1676.3 & $99.5 \%$ & $0.5 \%$ & $0.0 \%$ & 3120.5 & $-42.0 \%$ & $33.9 \%$ \\
\hline 32 & Zambia & 251 & 2.9 & 1059.9 & $99.9 \%$ & $0.1 \%$ & $0.1 \%$ & 2237.1 & $-26.0 \%$ & $43.0 \%$ \\
\hline 33 & Uganda & 226 & 2.7 & 1076.8 & $99.9 \%$ & $0.1 \%$ & $0.0 \%$ & 1248.1 & $-49.0 \%$ & $193.7 \%$ \\
\hline 34 & Bulgaria & 27 & 2.5 & 441.8 & $99.1 \%$ & $0.2 \%$ & $0.8 \%$ & 678.4 & $-32.7 \%$ & $-11.8 \%$ \\
\hline 35 & $\begin{array}{l}\text { Democratic People's Republic of } \\
\text { Korea }\end{array}$ & 116 & 2.2 & 538.8 & $99.9 \%$ & $0.1 \%$ & $0.0 \%$ & 789.3 & $32.2 \%$ & $-22.3 \%$ \\
\hline 36 & Nepal & 149 & 2.1 & 884.8 & $98.3 \%$ & $0.0 \%$ & $1.6 \%$ & 1195.4 & $-38.0 \%$ & $26.7 \%$ \\
\hline 37 & Democratic Republic of the Congo & 250 & 2.0 & 2591.8 & $100.0 \%$ & $0.0 \%$ & $0.0 \%$ & 3001.1 & $9.7 \%$ & $141.7 \%$ \\
\hline 38 & Venezuela (Bolivarian Republic of) & 236 & 2.0 & 552.2 & $97.1 \%$ & $0.3 \%$ & $2.6 \%$ & 1255.4 & $-43.4 \%$ & $-1.7 \%$ \\
\hline 39 & Austria & 11 & 2.0 & 204.4 & $98.3 \%$ & $0.7 \%$ & $1.0 \%$ & 353.9 & $-14.4 \%$ & $3.8 \%$ \\
\hline 40 & Cameroon & 32 & 2.0 & 1071.9 & $99.2 \%$ & $0.6 \%$ & $0.2 \%$ & 1718.6 & $0.9 \%$ & $425.0 \%$ \\
\hline \multicolumn{11}{|c|}{ Countries that produce the rest $5 \%$ of maize } \\
\hline 41 & Mali & 133 & 2.0 & 789.2 & $100.0 \%$ & $0.0 \%$ & $0.0 \%$ & 2003.0 & $-41.4 \%$ & $453.9 \%$ \\
\hline 42 & Bangladesh & 16 & 1.9 & 279.9 & $89.8 \%$ & $0.7 \%$ & $9.6 \%$ & 421.9 & $-84.6 \%$ & $9381.2 \%$ \\
\hline 43 & Greece & 84 & 1.9 & 174.8 & $59.9 \%$ & $0.0 \%$ & $40.1 \%$ & 423.6 & $-12.1 \%$ & $-22.6 \%$ \\
\hline 44 & Guatemala & 89 & 1.8 & 867.3 & $99.6 \%$ & $0.0 \%$ & $0.3 \%$ & 1583.6 & $-10.9 \%$ & $33.7 \%$ \\
\hline 45 & Croatia & 98 & 1.8 & 271.2 & $95.7 \%$ & $4.2 \%$ & $0.1 \%$ & 625.7 & $-33.8 \%$ & $-24.5 \%$ \\
\hline 46 & Ghana & 81 & 1.8 & 969.6 & $100.0 \%$ & $0.0 \%$ & $0.0 \%$ & 1712.1 & $-32.7 \%$ & $84.4 \%$ \\
\hline 47 & Myanmar & 28 & 1.7 & 455.0 & $94.7 \%$ & $1.5 \%$ & $3.8 \%$ & 486.6 & $-58.7 \%$ & $222.5 \%$ \\
\hline 48 & Colombia & 44 & 1.7 & 520.5 & $99.5 \%$ & $0.5 \%$ & $0.0 \%$ & 1132.1 & $-56.8 \%$ & $-26.1 \%$ \\
\hline 49 & Peru & 170 & 1.6 & 496.0 & $59.2 \%$ & $0.0 \%$ & $40.8 \%$ & 1582.2 & $-36.8 \%$ & $18.5 \%$ \\
\hline 50 & Burkina Faso & 233 & 1.6 & 848.4 & $99.9 \%$ & $0.0 \%$ & $0.1 \%$ & 2833.9 & $-45.3 \%$ & $310.4 \%$ \\
\hline 51 & Angola & 7 & 1.6 & 1560.9 & $99.3 \%$ & $0.1 \%$ & $0.6 \%$ & 5516.7 & $-65.3 \%$ & $112.4 \%$ \\
\hline 52 & Iran (Islamic Republic of) & 102 & 1.5 & 227.8 & $11.2 \%$ & $0.0 \%$ & $88.8 \%$ & 1045.8 & $-45.5 \%$ & $1406.1 \%$ \\
\hline 53 & Mozambique & 144 & 1.5 & 1646.1 & $98.9 \%$ & $0.3 \%$ & $0.8 \%$ & 6492.6 & $-60.6 \%$ & $62.7 \%$ \\
\hline 54 & Republic of Moldova & 146 & 1.5 & 468.6 & $99.9 \%$ & $0.0 \%$ & $0.1 \%$ & 1281.7 & $31.5 \%$ & $49.8 \%$ \\
\hline 55 & Ecuador & 58 & 1.4 & 438.9 & $97.3 \%$ & $0.4 \%$ & $2.3 \%$ & 1461.0 & $-69.4 \%$ & $-5.4 \%$ \\
\hline 56 & Chile & 40 & 1.4 & 125.3 & $50.0 \%$ & $0.0 \%$ & $49.9 \%$ & 320.3 & $-28.2 \%$ & $32.5 \%$ \\
\hline 57 & Lao People's Democratic Republic & 120 & 1.4 & 233.0 & $100.0 \%$ & $0.0 \%$ & $0.0 \%$ & 572.8 & $-74.5 \%$ & $616.1 \%$ \\
\hline 58 & Slovakia & 199 & 1.3 & 205.3 & $90.9 \%$ & $8.1 \%$ & $1.0 \%$ & 573.8 & $-17.2 \%$ & $79.2 \%$ \\
\hline
\end{tabular}




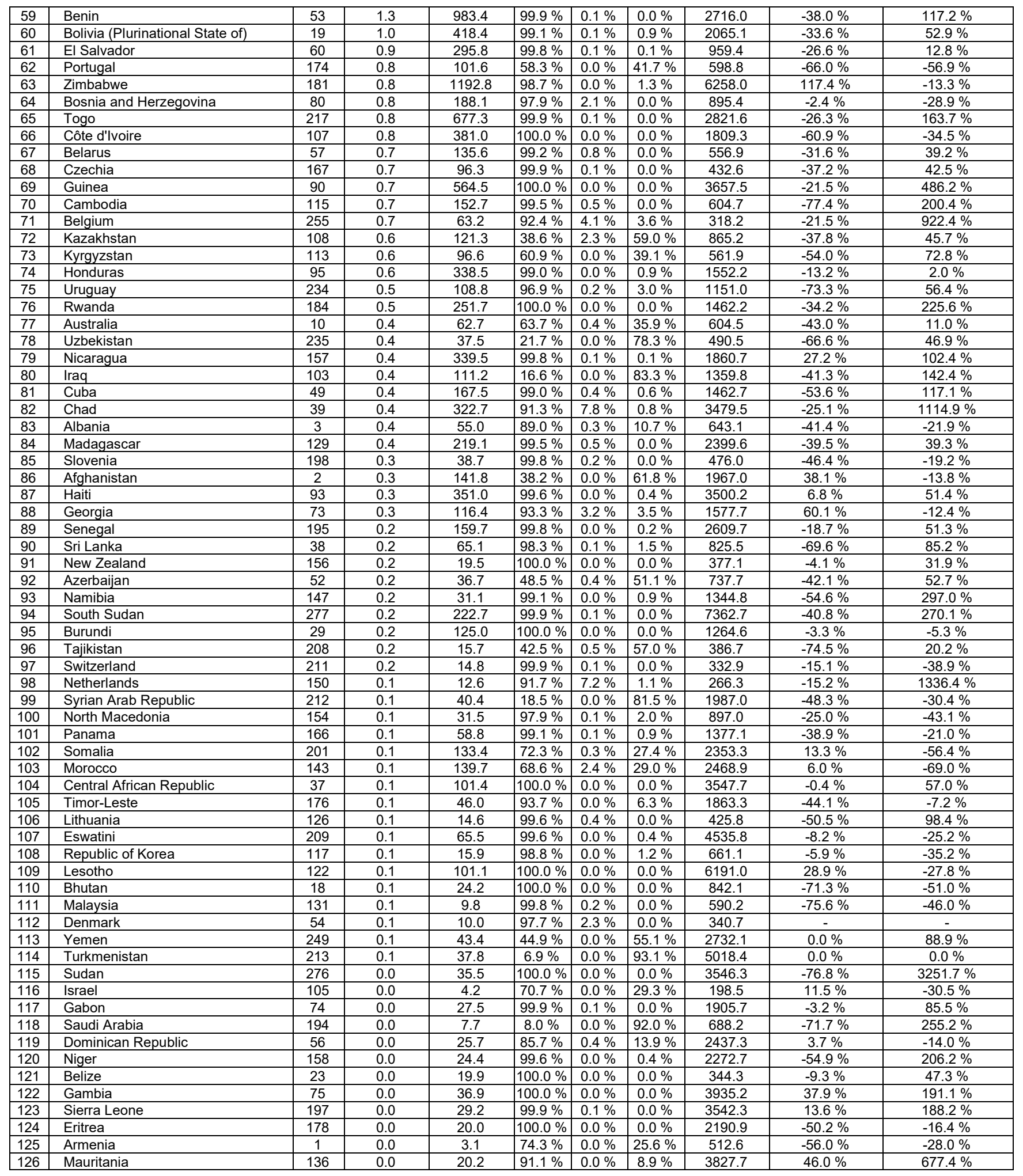




\begin{tabular}{|c|c|c|c|c|c|c|c|c|c|c|}
\hline 127 & Botswana & 20 & 0.0 & 54.8 & $76.8 \%$ & $0.0 \%$ & $23.2 \%$ & 5519.1 & $14.1 \%$ & $-21.7 \%$ \\
\hline 128 & Oman & 221 & 0.0 & 1.5 & $100.0 \%$ & $0.0 \%$ & $0.0 \%$ & 92.3 & - & - \\
\hline 129 & Papua New Guinea & 168 & 0.0 & 2.2 & $99.9 \%$ & $0.1 \%$ & $0.0 \%$ & 560.9 & $-68.3 \%$ & $127.0 \%$ \\
\hline 130 & Costa Rica & 48 & 0.0 & 5.8 & $99.8 \%$ & $0.2 \%$ & $0.0 \%$ & 1368.6 & $-13.3 \%$ & $-89.6 \%$ \\
\hline 131 & Congo & 46 & 0.0 & 13.4 & $99.7 \%$ & $0.3 \%$ & $0.0 \%$ & 2472.1 & $-11.1 \%$ & $-39.4 \%$ \\
\hline 132 & Guinea-Bissau & 175 & 0.0 & 7.0 & $100.0 \%$ & $0.0 \%$ & $0.0 \%$ & 3889.8 & $-5.5 \%$ & $-37.0 \%$ \\
\hline 133 & Jordan & 112 & 0.0 & 0.9 & $83.1 \%$ & $0.0 \%$ & $16.9 \%$ & 117.6 & $-2.7 \%$ & $272.1 \%$ \\
\hline 134 & Kuwait & 118 & 0.0 & 1.0 & $1.6 \%$ & $0.0 \%$ & $98.4 \%$ & 772.5 & $-1.8 \%$ & $1556.0 \%$ \\
\hline 135 & Trinidad and Tobago & 220 & 0.0 & 1.5 & $100.0 \%$ & $0.0 \%$ & $0.0 \%$ & 1385.0 & $47.3 \%$ & $77.9 \%$ \\
\hline 136 & Guyana & 91 & 0.0 & 2.9 & $99.5 \%$ & $0.5 \%$ & $0.0 \%$ & 2499.7 & $-10.5 \%$ & $34.9 \%$ \\
\hline 137 & Lebanon & 121 & 0.0 & 0.9 & $52.1 \%$ & $0.0 \%$ & $47.9 \%$ & 1325.0 & $-55.9 \%$ & $-47.3 \%$ \\
\hline 138 & Libya & 124 & 0.0 & 1.5 & $90.8 \%$ & $9.2 \%$ & $0.0 \%$ & 176.7 & $-42.2 \%$ & $3.2 \%$ \\
\hline 139 & Montenegro & 273 & 0.0 & 0.6 & $99.9 \%$ & $0.1 \%$ & $0.0 \%$ & 749.9 & $-27.1 \%$ & $-82.4 \%$ \\
\hline 140 & Jamaica & 109 & 0.0 & 2.3 & $100.0 \%$ & $0.0 \%$ & $0.0 \%$ & 3754.3 & $-4.8 \%$ & $-19.2 \%$ \\
\hline 141 & Algeria & 4 & 0.0 & 0.7 & $32.5 \%$ & $0.3 \%$ & $67.2 \%$ & 487.4 & $-45.7 \%$ & $-31.2 \%$ \\
\hline 142 & Luxembourg & 256 & 0.0 & 0.2 & $100.0 \%$ & $0.0 \%$ & $0.0 \%$ & 404.7 & $-3.0 \%$ & $83.5 \%$ \\
\hline 143 & Fiji & 66 & 0.0 & 0.3 & $100.0 \%$ & $0.0 \%$ & $0.0 \%$ & 1036.6 & $-15.2 \%$ & $-49.4 \%$ \\
\hline 144 & Bahamas & 12 & 0.0 & 0.1 & $100.0 \%$ & $0.0 \%$ & $0.0 \%$ & 338.4 & $-79.5 \%$ & $-84.3 \%$ \\
\hline 145 & Vanuatu & 155 & 0.0 & 1.5 & $100.0 \%$ & $0.0 \%$ & $0.0 \%$ & 225.6 & $-81.7 \%$ & $-84.6 \%$ \\
\hline 146 & Qatar & 179 & 0.0 & 0.1 & $2.2 \%$ & $0.0 \%$ & $97.8 \%$ & 515.8 & $-0.9 \%$ & $2226.2 \%$ \\
\hline 147 & Mauritius & 137 & 0.0 & 0.1 & $100.0 \%$ & $0.0 \%$ & $0.0 \%$ & 394.4 & $-37.4 \%$ & $-91.9 \%$ \\
\hline 148 & Japan & 110 & 0.0 & 0.1 & $90.5 \%$ & $9.5 \%$ & $0.0 \%$ & 1453.2 & $-15.7 \%$ & $-84.3 \%$ \\
\hline 149 & Suriname & 207 & 0.0 & 0.0 & $99.4 \%$ & $0.6 \%$ & $0.0 \%$ & 1749.3 & $-36.0 \%$ & $-81.5 \%$ \\
\hline
\end{tabular}


Table S4. Annual average global maize simulation outputs and water footprints during 1986-2016. CWU is crop water use and WF is unit water footprint (g - green, bc - blue from capillary rise, bi - blue from irrigation).

\begin{tabular}{|c|c|c|c|c|c|c|c|c|c|c|c|c|c|c|c|c|}
\hline \multirow{3}{*}{ Year } & \multicolumn{5}{|c|}{ Rainfed systems } & \multicolumn{5}{|c|}{ Irrigated systems } & \multirow{3}{*}{$\begin{array}{l}\text { Yield } \\
\text { scaling } \\
\text { factor }\end{array}$} & \multicolumn{5}{|c|}{ Weighted average } \\
\hline & \multirow{2}{*}{$\begin{array}{c}\text { Harvested } \\
\text { area } \\
\left(10^{6}{\left.\text { ha } y^{-1}\right)}^{-1}\right.\end{array}$} & \multirow{2}{*}{$\begin{array}{c}\text { Simulated } \\
\text { yield } \\
\left(\mathrm{t} \mathrm{ha}^{-1} \mathrm{y}^{-1}\right)\end{array}$} & \multirow{2}{*}{$\underset{\left(\mathrm{mm} \mathrm{y}^{-1}\right)}{\mathbf{C W U}}$} & $W_{g}$ & $W_{b c}$ & \multirow{2}{*}{ 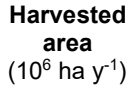 } & \multirow{2}{*}{$\begin{array}{c}\text { Simulated } \\
\text { yield } \\
\left(\mathrm{t} \mathrm{ha-1} \mathrm{y}^{-1}\right)\end{array}$} & \multirow{2}{*}{$\left|\underset{\left(\mathrm{mm} \mathrm{y}^{-1}\right)}{\mathbf{C W U}}\right|$} & $W F_{g}$ & $\mathbf{W F}_{b i}$ & & \multirow{2}{*}{ 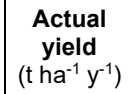 } & $W F_{g}$ & $W^{\prime} F_{c}$ & $W F_{b i}$ & Unit WF \\
\hline & & & & $\left(\mathrm{m}^{3} \mathrm{t}^{-1}\right.$ & $\left.y^{-1}\right)$ & & & & $\left(m^{3} \mathrm{t}\right.$ & $\left.-1 y^{-1}\right)$ & & & \multicolumn{4}{|c|}{$\left(m^{3} t^{-1} y^{-1}\right)$} \\
\hline 1986 & 113.1 & 13.28 & 385.8 & 1053.9 & 11.1 & 18.7 & 14.85 & 459.7 & 693.4 & 355.0 & $26.6 \%$ & 3.67 & 992.6 & 9.2 & 60.3 & 1062.2 \\
\hline 1987 & 111.1 & 12.77 & 383.4 & 1138.6 & 15.0 & 18.9 & 14.69 & 457.9 & 718.9 & 366.8 & $25.4 \%$ & 3.4 & 1062.9 & 12.3 & 66.2 & 1141.3 \\
\hline 1988 & 111.1 & 12.56 & 375.5 & 1190.8 & 22.1 & 18.9 & 14.59 & 450.9 & 682.6 & 384.5 & $25.5 \%$ & 3.22 & 1093.9 & 17.9 & 73.3 & 1185.1 \\
\hline 1989 & 112.4 & 13.40 & 385.1 & 1095.9 & 15.5 & 19.4 & 14.85 & 452.5 & 648.0 & 366.1 & $26.3 \%$ & 3.59 & 1013.9 & 12.7 & 67.0 & 1093.6 \\
\hline 1990 & 111.5 & 12.90 & 387.1 & $\mid 1079.7$ & 13.0 & 19.6 & 14.58 & 459.5 & 653.1 & 354.3 & $27.4 \%$ & 3.66 & 1000.2 & 10.5 & 66.0 & 1076.8 \\
\hline 1991 & 113.5 & 12.76 & 382.1 & 1061.0 & 14.3 & 20.1 & 14.53 & 456.7 & 629.9 & 333.0 & $28.1 \%$ & 3.7 & 978.0 & 11.6 & 64.2 & 1053.7 \\
\hline 1992 & 115.9 & 12.74 & 364.0 & 957.6 & 14.2 & 20.8 & 14.90 & 449.1 & 607.7 & 310.8 & $27.9 \%$ & 3.82 & 889.5 & 11.5 & 60.5 & 961.5 \\
\hline 1993 & 111.0 & 12.86 & 376.2 & 1012.7 & 11.9 & 20.4 & 14.98 & 450.3 & 606.4 & 303.9 & $28.1 \%$ & 3.82 & 931.1 & 9.5 & 61.0 & 1001.7 \\
\hline 1994 & 116.8 & 13.06 & 378.3 & 981.0 & 12.1 & 21.5 & 14.38 & 453.2 & 618.7 & 329.3 & $28.7 \%$ & 3.92 & 912.5 & 9.8 & 62.3 & 984.6 \\
\hline 1995 & 114.1 & 12.64 & 373.9 & 982.4 & 13.2 & 21.7 & 14.55 & 449.5 & 587.9 & 320.2 & $29.1 \%$ & 3.87 & 901.9 & 10.5 & 65.4 & 977.8 \\
\hline 1996 & 116.0 & 13.81 & 387.8 & 946.7 & 12.1 & 23.3 & 14.89 & 433.1 & 575.9 & 268.9 & $29.7 \%$ & 4.2 & 871.0 & 9.6 & 54.9 & 935.5 \\
\hline 1997 & 117.4 & 13.75 & 390.9 & 933.1 & 12.8 & 23.4 & 14.51 & 458.8 & 578.5 & 306.2 & $30.2 \%$ & 4.27 & 861.5 & 10.3 & 61.8 & 933.6 \\
\hline 1998 & 114.3 & 13.35 & 383.8 & 907.8 & 9.3 & 24.4 & 14.35 & 439.5 & 564.5 & 277.6 & $31.4 \%$ & 4.33 & 835.1 & 7.3 & 58.8 & 901.2 \\
\hline 1999 & 112.7 & 13.31 & 390.2 & 893.4 & 12.1 & 24.6 & 14.55 & 454.9 & 560.0 & 277.5 & $32.1 \%$ & 4.46 & 820.6 & 9.4 & 60.6 & 890.6 \\
\hline 2000 & 112.9 & 13.03 & 381.3 & 896.7 & 15.5 & 24.1 & 14.46 & 466.7 & 504.9 & 354.9 & $32.5 \%$ & 4.35 & 811.0 & 12.1 & 77.7 & 900.8 \\
\hline 2001 & 112.9 & 13.21 & 387.8 & 889.9 & 14.2 & 24.5 & 14.45 & 461.7 & 521.5 & 320.8 & $32.9 \%$ & 4.46 & 809.2 & 11.1 & 70.3 & 890.5 \\
\hline 2002 & 112.8 & 12.53 & 384.8 & 896.2 & 13.7 & 24.8 & 14.48 & 469.6 & 494.5 & 350.2 & $33.6 \%$ & 4.41 & 804.9 & 10.6 & 79.6 & 895.1 \\
\hline 2003 & 118.9 & 12.84 & 383.7 & 880.1 & 13.2 & 25.7 & 14.72 & 456.9 & 483.7 & 311.7 & $33.7 \%$ & 4.5 & 790.5 & 10.2 & 70.4 & 871.2 \\
\hline 2004 & 120.7 & 13.80 & 393.3 & 813.2 & 10.4 & 26.9 & 14.82 & 451.6 & 498.3 & 254.1 & $34.7 \%$ & 4.97 & 743.9 & 8.1 & 55.9 & 807.9 \\
\hline 2005 & 121.1 & 12.94 & 394.5 & 855.1 & 10.6 & 27.2 & 14.36 & 459.9 & 487.2 & 281.6 & $35.9 \%$ & 4.77 & 770.7 & 8.1 & 64.6 & 843.4 \\
\hline 2006 & 120.8 & 13.06 & 386.2 & 834.3 & 12.0 & 27.6 & 14.23 & 449.2 & 479.0 & 274.7 & $35.9 \%$ & 4.79 & 752.1 & 9.2 & 63.6 & 824.8 \\
\hline 2007 & 129.9 & 13.06 & 390.7 & 808.9 & 15.5 & 29.4 & 14.44 & 445.6 & 469.6 & 251.6 & $37.2 \%$ & 4.96 & 731.0 & 12.0 & 57.8 & 800.7 \\
\hline 2008 & 134.0 & 13.71 & 398.7 & 799.4 & 10.3 & 29.7 & 14.62 & 446.4 & 479.8 & 239.1 & $36.5 \%$ & 5.12 & 729.0 & 8.1 & 52.6 & 789.7 \\
\hline 2009 & 129.7 & 13.45 & 389.9 & 771.1 & 10.8 & 29.7 & 14.62 & 454.7 & 468.9 & 247.7 & $37.3 \%$ & 5.2 & 702.4 & 8.4 & 56.3 & 767.1 \\
\hline 2010 & 133.7 & 13.32 & 390.5 & 790.2 & 8.8 & 31.0 & 14.19 & 437.3 & 481.4 & 229.6 & $37.7 \%$ & 5.09 & 720.2 & 6.8 & 52.1 & 779.0 \\
\hline 2011 & 140.0 & 13.35 & 393.8 & 763.5 & 10.6 & 31.8 & 14.35 & 443.0 & 450.5 & 241.1 & $38.9 \%$ & 5.28 & 693.1 & 8.2 & 54.2 & 755.5 \\
\hline 2012 & 147.0 & 12.09 & 373.5 & 816.1 & 17.3 & 33.4 & 14.26 & 457.7 & 414.5 & 291.0 & $39.9 \%$ & 4.8 & 715.8 & 13.0 & 72.6 & 801.5 \\
\hline 2013 & 152.9 & 13.17 & 387.2 & 728.5 & 10.8 & 34.7 & 14.18 & 446.2 & 450.0 & 231.8 & $40.6 \%$ & 5.41 & 666.3 & 8.4 & 51.8 & 726.5 \\
\hline 2014 & 151.5 & 13.49 & 389.1 & 715.7 & 8.9 & 34.9 & 14.62 & 447.0 & 429.3 & 234.9 & $40.6 \%$ & 5.58 & 651.1 & 6.9 & 53.0 & 710.9 \\
\hline 2015 & 152.8 & 12.97 & 382.9 & 699.5 & 10.6 & 38.5 & 14.34 & 440.1 & 433.9 & 225.8 & $41.7 \%$ & 5.58 & 635.6 & 8.1 & 54.3 & 698.0 \\
\hline 2016 & 157.7 & 13.01 & 384.9 & 707.7 & 8.9 & 38.9 & 14.00 & 435.4 & 463.1 & 196.3 & $42.1 \%$ & 5.56 & 650.3 & 6.8 & 46.1 & 703.2 \\
\hline
\end{tabular}




\section{References}

Barbieri, P., Echarte, L., Della Maggiora, A., Sadras, V. O., Echeverria, H., and Andrade, F. H.: Maize Evapotranspiration and Water-Use Efficiency in Response to Row Spacing, Agron.j., 104, 939-944, https://doi.org/10.2134/agronj2012.0014, 2012.

Chukalla, A. D., Krol, M. S., and Hoekstra, A. Y.: Green and blue water footprint reduction in irrigated agriculture: effect of irrigation techniques, irrigation strategies and mulching, Hydrol. Earth Syst. Sci., 19, 4877-4891, https://doi.org/10.5194/hess-19-4877-2015, 2015.

FAOSTAT: http://www.fao.org/faostat, last access: 15 May 2021.

Irmak, S. and Djaman, K.: Effects of Planting Date and Density on Plant Growth, Yield, Evapotranspiration, and Water Productivity of Subsurface Drip-Irrigated and Rainfed Maize, Trans. ASABE, 59, 1235-1256, https://doi.org/10.13031/trans.59.11169, 2016.

Jägermeyr, J., Müller, C., Ruane, A. C., Elliott, J., Balkovic, J., Castillo, O., Faye, B., Foster, I., Folberth, C., Franke, J. A., Fuchs, K., Guarin, J. R., Heinke, J., Hoogenboom, G., Iizumi, T., Jain, A. K., Kelly, D., Khabarov, N., Lange, S., Lin, T.-S., Liu, W., Mialyk, O., Minoli, S., Moyer, E. J., Okada, M., Phillips, M., Porter, C., Rabin, S. S., Scheer, C., Schneider, J. M., Schyns, J. F., Skalsky, R., Smerald, A., Stella, T., Stephens, H., Webber, H., Zabel, F., and Rosenzweig, C.: Climate impacts on global agriculture emerge earlier in new generation of climate and crop models, Nat Food, https://doi.org/10.1038/s43016021-00400-y, 2021.

Kahlown, M. A., Ashraf, M., and Zia-ul-Haq: Effect of shallow groundwater table on crop water requirements and crop yields, Agricultural Water Management, 76, 24-35, https://doi.org/10.1016/j.agwat.2005.01.005, 2005.

Klein Goldewijk, K., Beusen, A., Doelman, J., and Stehfest, E.: Anthropogenic land use estimates for the Holocene - HYDE 3.2, Earth Syst. Sci. Data, 9, 927-953, https://doi.org/10.5194/essd-9-927-2017, 2017.

Mkhabela, M. S. and Bullock, P. R.: Performance of the FAO AquaCrop model for wheat grain yield and soil moisture simulation in Western Canada, Agricultural Water Management, 110, 16-24, https://doi.org/10.1016/j.agwat.2012.03.009, 2012.

Rossato, L., Alvalá, R. C. dos S., Marengo, J. A., Zeri, M., Cunha, A. P. M. do A., Pires, L. B. M., and Barbosa, H. A.: Impact of Soil Moisture on Crop Yields over Brazilian Semiarid, Front. Environ. Sci., 5, 73, https://doi.org/10.3389/fenvs.2017.00073, 2017.

Siebert, S., Kummu, M., Porkka, M., Döll, P., Ramankutty, N., and Scanlon, B. R.: A global data set of the extent of irrigated land from 1900 to 2005, Hydrol. Earth Syst. Sci., 19, 1521-1545, https://doi.org/10.5194/hess-19-1521-2015, 2015.

Vanuytrecht, E., Raes, D., Steduto, P., Hsiao, T. C., Fereres, E., Heng, L. K., Garcia Vila, M., and Mejias Moreno, P.: AquaCrop: FAO's crop water productivity and yield response model, Environmental Modelling \& Software, 62, 351-360, https://doi.org/10.1016/j.envsoft.2014.08.005, 2014.

Yu, Q., You, L., Wood-Sichra, U., Ru, Y., Joglekar, A. K. B., Fritz, S., Xiong, W., Lu, M., Wu, W., and Yang, P.: A cultivated planet in 2010 - Part 2: The global gridded agricultural-production maps, Earth Syst. Sci. Data, 12, 3545-3572, https://doi.org/10.5194/essd-12-3545-2020, 2020. 